\title{
Karolina Józefowicz
}

Uniwersytet Przyrodniczy w Poznaniu

Wydziat Ekonomiczno-Społeczny

karolina.jozefowicz@up.poznan.pl

\section{Starość demograficzna miast województwa wielkopolskiego w latach 1995-2018}

\begin{abstract}
Zarys treści: Celem artykułu jest określenie skali zaawansowania procesu starzenia się ludności miast województwa wielkopolskiego. Wykorzystano do tego podział zaproponowany przez Prochownikową, w którym wyodrębniono siedem stopni starości. Zakres przestrzenny obejmował 108 miast województwa wielkopolskiego. W celu zaobserwowania zmian w czasie badania dotyczyły lat 1995, 2000, 2005, 2010, 2015 oraz 2018. Dynamiczne ujęcie pozwoliło zobrazować skalę i ewaluację problemu starości demograficznej Wielkopolskich miast. Na podstawie wyodrębnionych typów stwierdzono, że do 2010 r. w miastach obserwowano początkowy stan starości. Do 2018 r. odsetek osób starszych przekroczył we wszystkich ośrodkach miejskich 15\% (zaawansowany stan starości), a w przypadku Kalisza i Konina 25\%, czyli skalę anormalnie wysokiego poziomu starości mieszkańców.
\end{abstract}

Słowa kluczowe: demografia, starzejące się społeczeństwo, miasta, województwo wielkopolskie

\section{Wprowadzenie}

Starzenie się ludności przybrało wymiar zjawiska o niespotykanej wcześniej skali. Jako współczesny proces demograficzny swym zasięgiem obejmuje przede wszystkim kraje wysoko rozwinięte (Kurek 2008, Abramowska-Kmon 2011, Żołędowski 2012, Bloom, Luca 2016), gdzie odsetek osób starszych wzrasta corocznie średnio o 2,4 p.p. Prognozy przewidują, że w tym tempie do $2050 \mathrm{r}$. populacja seniorów będzie stanowić 32\% ogółu ludności (World Population Prospects... 2011). Na poziomie globalnym odsetek osób starszych wynosił około 9\% (w 2019 r.) i do 2050 r. szacowany jest wzrost do 15,9\% (World Population Prospects... 2019). Najbardziej starzejące się populacje obserwuje się w Europie i Ameryce Północnej. W krajach, takich jak Włochy, Niemcy czy Bułgaria, odsetek osób w wieku powyżej 65 lat przekracza odsetek dzieci poniżej 15 roku życia (Vaupel, Kistowski 2008). 
Historyczne przemiany demograficzne nawiązują do około 1800 r., jako pierwszego etapu transformacji demograficznej (spadek śmietelności, wzrost oczekiwanej długości życia), w którym dostrzeżono sygnały starzenia ludności (Bloom, Luca 2016), a później do końca XIX w., kiedy w krajach rozwiniętych wskaźniki dzietności weszły w fazę trwałego spadku. Uznaje się jednak, że proces starzenia się światowej populacji ma względnie krótką historię, wskazując na ostatni kwartał XX w., wówczas za zjawisko globalne uznano spadek płodności (Rowland 2009). Prognozy wskazują, że pierwsza połowa XXI w. będzie kluczowa, z punktu widzenia nasilenia zjawiska, jednak probabilistyczne założenia Sandersona i in. (2018) pokazują zakończenie problemu starzenia się populacji długo przed końcem XXI w.

Proces starzenia się społeczeństwa w Polsce obserwuje się szczególnie od lat 90. XX w. (Kurek 2008), jednak nie jest to zjawisko nowe. Pierwsze jego symptomy (mimo niewielkich rozmiarów), podobnie jak w krajach zachodnich, pojawiły się $\mathrm{w}$ okresie międzywojennym. W latach 60 . XX w. zaobserwowano poważniejsze nasilenie, szczególnie za sprawą emigracji ludności do miast, ale $z$ końcem lat 80. XX w. wskutek m.in. zahamowania emigracji czy spadku urodzeń problem starzenia się mieszkańców dotknął również miasta (Długosz, Rachwał 2000).

W Polsce pod koniec 2018 r. osoby starsze stanowily prawie $25 \%$ mieszkańców, a według prognoz w 2050 r. odsetek ludności w wieku 60 lat i więcej wyniesie około 40\% (Sytuacja osób starszych... 2020). Problem starzenia się społeczeństwa w większym stopniu dosięga miast aniżeli obszarów wiejskich. W 2018 r. 26,9\% mieszkańców miast stanowiły osoby w wieku senioralnym ( $21,5 \%$ na wsi), do końca horyzontu prognozy GUS udział osób starszych zbliży się do 35\% (Sytuacja demograficzna osób starszych... 2014).

Sytuacja demograficzna, zmienność jej uwarunkowań jest przedmiotem zainteresowania przedstawicieli nauk społecznych i jednym z priorytetów polityki społecznej. Zjawiska, jakie zachodzą w tej dziedzinie znajdują bowiem odzwierciedlenie w prowadzonej polityce, a co za tym idzie - decyzjach, podejmowanych w wymiarze krajowym czy lokalnym. Proces starzenia się społeczeństwa w konsekwencji jest wyzwaniem, które rozszerza się na wszystkie sfery życia społeczno-gospodarczego (m.in. ochrona zdrowia, rynek pracy, opieka społeczna, wydatki publiczne) (Abramowska-Kmon 2011, Ageing in the Twenty-First... 2012, Bloom, Luca 2016, Filas-Przybył 2017).

Pierwsze prace poświęcone starzeniu się społeczeństwa w Polsce pojawiły się pod koniec lat 50. XX w. Wówczas demografowie i geografowie zwrócili uwagę na zmiany zachodzące w strukturze wieku (Kurek 2008). W dobie słabnącej od końca lat 80. XX w. dynamiki rozwoju ludności jest to zjawisko jak najbardziej aktualne, również w miastach. Miasta, które kiedyś dzięki swojej sile przyciągania (czynniki społeczno-gospodarcze) wykazywały intensywny napływ ludności (chodzi przede wszystkim o miasta duże), obecnie zmagają się ze zjawiskiem suburbanizacji (Górecka, Kozieł 2004). Trendy demograficzne są zatem współczesnym wyzwaniem dla miast, w efekcie czego problematyka starzejącego się społeczeństwa uwzględniana jest nie tylko $\mathrm{w}$ polityce senioralnej, ale również 
programach odnowy miast, w których za cele stawiane są rozwiązania służące poprawie sytuacji osób starszych oraz odpowiadające potrzebom tych osób (Labus 2013).

Jeśli mowa o starzeniu się miast, kluczowe jest zwrócenie uwagi na jego uwarunkowania. Identyfikacja zjawiska jest składową kilku zmiennych. Starzenie się ludności z definicji oznacza „zwiększenie odsetka osób starszych, przy jednoczesnym zmniejszeniu odsetka dzieci" (Sytuacja demograficzna osób starszych... 2014, s. 2). Stąd też do uwarunkowań starzenia się miast $z$ jednej strony zaliczamy przyrost naturalny i trendy w modelu rodziny czy wydłużającym się czasie trwania życia i umieralności (Kurek 2008), z drugiej strony - zjawisko migracji ludności, a w zasadzie emigracji, które $\mathrm{w}$ efekcie zaburza proporcje $\mathrm{w}$ strukturze wieku ludności danego miasta (Janiszewska, Dmochowska-Dudek 2017). Zjawisko emigracji, czyli odpływu ludności, przede wszystkim młodej, prowadzi w konsekwencji do wyraźnych zmian. Wynika to z faktu, że ze zmianą miejsca zamieszkania wiąże się ubytek zarówno w grupie osób w wieku produkcyjnym, jak i przedprodukcyjnym. W rezultacie rośnie odsetek osób w wieku poprodukcyjnym w strukturze ludności danego miasta.

\section{Material i metodyka}

Materiał empiryczny w tym artykule opierał się na danych dotyczących udziału osób w wieku poprodukcyjnym (powyżej 65 roku życia w przypadku mężczyzn i 60 roku życia w przypadku kobiet) w ogólnej liczbie ludności. Dynamiczne ujęcie badań obejmowało analizę zmian poziomu starości miast w latach 1995-2018 w pięcioletnich odstępach czasu $(1995,2000,2005,2010,2015$ i 2018).

Wskazane lata wiązały się $z$ jednej strony $z$ próbą obserwacji zmian, jakie nastąpiły $w$ tych odstępach czasu, $z$ drugiej strony natomiast $-z$ dostępnością danych w Banku Danych Lokalnych GUS. Zakres przestrzenny obejmował 108 miast województwa wielkopolskiego. Dokonując próby wskazania zależności między typem starości a wielkością miasta, w analizach wyróżniono trzy klasy wielkościowe ośrodków miejskich (miasta małe - liczące do 20 tys. mieszkańców, miasta średnie - od 20 do 100 tys. mieszkańców oraz miasta duże, z liczbą ludności przekraczającą 100 tys.).

Literatura przedmiotu obfituje w prace naukowe, w których omawiany był problem starzenia się społeczeństwa. Autorzy poruszali kwestie przyczyn (Czekanowski 2012, Miszczak 2015), konsekwencji i wyzwań (Global age-friendly... 2007) czy oddziaływań polityki społecznej w kontekście starzejącej się ludności (Ageing in Cities... 2015, Głoskowska 2015, Richert-Kaźmierska 2016, Kaplan, Inguanzo 2017, van Hoof i in. 2018). Dokonywano również przestrzennej analizy porównawczej zaawansowania procesu starzenia się (miast, powiatów, makroregionów czy krajów) za pomocy zróżnicowanych współczynników (Domański, Noworól 2010, Kowaleski, Majdzińska 2012, d’Albis, Collard 2013, Trzpiot, Ojrzyńska 2014, Podogrodzka 2016, Urbaniak 2017). Ponadto w literaturze naukowej spotkać można wiele skal, za pomocą których analizuje się kwestie starzenia 
się społeczeństwa. Autorem pierwszej klasyfikacji był Sundbärg, który w 1899 r. wyodrębnił typy struktur wieku ludności (Kurek 2008). W ślad za nim, z propozycją własnych skal zaawansowania procesu starzenia się społeczeństwa wyszli m.in. Sauvy (1948), Rosset (1967), Prochownikowa (1983) czy, jak wymienia Kurek (2008), demografowie ONZ, Beaujeu-Garnier, Sanderson i Scherbow.

W ramach badań skupiono się wyłącznie na klasyfikacji starości demograficznej miast województwa wielkopolskiego, pomijając aspekt uwarunkowań starzenia się społeczeństwa. Jest to celowe działanie autora, który w kolejnej publikacji zakłada podjęcie szerszych badań w tym zakresie, a mianowicie powiązanie wyodrębnionych typów starości miast województwa wielkopolskiego z uwarunkowaniami demograficznymi.

Tym samym w celu wyodrębnienia typów zaawansowania procesu starzenia się miast w Wielkopolsce posłużono się skalą zaproponowaną przez Prochownikową (1983) (tab. 1).

Tabela 1. Skala zaawansowania starzenia się ludności według Prochownikowej

\begin{tabular}{clc}
\hline Stopień & \multicolumn{1}{c}{ Określenie poziomu starości } & Udział osób w wieku poprodukcyjnym (\%) \\
\hline I & Młodość demograficzna & Poniżej 8,0 \\
II & Dojrzałość demograficzna & $8,0-9,9$ \\
III & Przedpole starzenia się & $10,0-11,9$ \\
IV & Początkowy stan starości & $12,0-14,9$ \\
V & Zaawansowany stan starości & $15,0-19,9$ \\
VI & Wysoki stan starości & $20,0-24,9$ \\
VII & Anormalnie wysoki stan starości & 25,0 i więcej \\
\hline
\end{tabular}

Źródło: Prochownikowa (1983, s. 122).

Kluczową kwestię, która poprzedza przejście do klasyfikacji zaawansowania procesu starzenia się ludności miast, jest przyjęcie dolnej granicy wieku ludności poprodukcyjnej, czyli progu starości demograficznej. Najczęściej wskazuje się granicę 60 lub 65 lat (Kowaleski 2003, Kurek 2008, Czekanowski 2012, Biały 2013, Długosz, Richert-Kaźmierska 2016, Urbaniak 2017, Antczak, Lewandowska-Gwarda 2018). W ramach badań przyjęto zatem, że ludność w wieku poprodukcyjnym to osoby powyżej 65 roku życia (w przypadku mężczyzn) i 60 roku życia (w przypadku kobiet).

\section{Wyniki badań}

Województwo wielkopolskie liczy 113 miast (91 miast małych ${ }^{1}, 18$ miast średnich i 2 miasta duże). W 2018 r. zamieszkiwało je prawie 1,882 mln osób. Wśród nich $22,7 \%$ były osoby starsze. Odsetek ten zmieniał się od 1995 r. i różnił w poszczególnych ośrodkach miejskich (tab. 2, ryc. 1-3).

1 W badaniu nie uwzględniono miast: Nekla, Chocz, Dobrzyca, Jaraczewo i Opatówek, które nie miały praw miejskich w całych analizowanym okresie. 
Tabela 2. Rozkład miast według typów starości w analizowanych latach

\begin{tabular}{|c|c|c|c|c|c|c|}
\hline \multirow{3}{*}{$\begin{array}{l}\text { Skala } \\
\text { starości }\end{array}$} & \multicolumn{6}{|c|}{ Miasta } \\
\hline & 1995 & 2000 & 2005 & 2010 & 2015 & 2018 \\
\hline & \multicolumn{6}{|c|}{ w liczbach bezwzględnych } \\
\hline I & 1 & 1 & 2 & 0 & 0 & 0 \\
\hline II & 9 & 3 & 1 & 2 & 0 & 0 \\
\hline III & 30 & 31 & 31 & 4 & 0 & 0 \\
\hline IV & 58 & 66 & 65 & 49 & 8 & 0 \\
\hline $\mathrm{V}$ & 10 & 7 & 9 & 53 & 72 & 50 \\
\hline VI & 0 & 0 & 0 & 0 & 28 & 56 \\
\hline \multirow[t]{2}{*}{ VII } & 0 & 0 & 0 & 0 & 0 & 2 \\
\hline & \multicolumn{6}{|c|}{ w odsetkach (\%) } \\
\hline I & 0,9 & 0,9 & 1,9 & 0,0 & 0,0 & 0,0 \\
\hline II & 8,3 & 2,8 & 0,9 & 1,9 & 0,0 & 0,0 \\
\hline III & 27,8 & 28,7 & 28,7 & 3,7 & 0,0 & 0,0 \\
\hline IV & 53,7 & 61,1 & 60,2 & 45,4 & 7,4 & 0,0 \\
\hline $\mathrm{V}$ & 9,3 & 6,5 & 8,3 & 49,1 & 66,7 & 46,3 \\
\hline VI & 0,0 & 0,0 & 0,0 & 0,0 & 25,9 & 51,9 \\
\hline VII & 0,0 & 0,0 & 0,0 & 0,0 & 0,0 & 1,9 \\
\hline
\end{tabular}

Źródło: opracowanie własne na podstawie danych BDL, GUS.

W 1995 r. miasta województwa wielkopolskiego wykazywały przedpole (typ III) i początkowy stan starzenia się ludności (typ IV). Taka skala utrzymywała się do 2005 r. W kolejnych okresach doszło do wyraźnych przesunięć poziomu starości. W 2010 r. prawie połowę miast dosięgnął zaawansowany stan starości, podczas gdy jeszcze pięć lat wcześniej odsetek tego typu ośrodków miejskich nie przekraczał $10 \%$. Ostatnie dwa rozpatrywane lata to dla miast wielkopolski okres dalszego nasilenia zjawiska starzenia się ludności. Było to szczególnie widoczne w typie VI (wysoki stan starości). W 2015 r. w przypadku $1 / 4$ miast zaobserwowano wysoki stan starości (udział osób $\mathrm{w}$ wieku poprodukcyjnym wynosił 20,0-24,9\%), natomiast pięć lat wcześniej (2010 r.) w żadnym ośrodku miejskim odsetek osób starszych nie przekroczył 20\%. Obserwując proces zaawansowania problemu starości od 2015 r., można stwierdzić, że wystarczyły trzy lata, by odsetek osób starszych zwiększył się dwukrotnie (w $2018 \mathrm{r}$. $\mathrm{W}$ ponad połowie miast osoby $\mathrm{w}$ wieku poprodukcyjnym stanowiły od 20,0 do 24,9\% mieszkańców).

Problem starości w 1995 r. był widoczny w przeważającej części miast. Jedynie o 10 miastach można było mówić jako o ośrodkach młodych demograficznie (Murowana Goślina) oraz dojrzałych demograficznie (Witkowo, Swarzędz, Śrem, Słupca, Konin, Książ Wielkopolski, Turek, Piła, Raszków). W tym samym okresie w 58 ośrodkach miejskich problem starości demograficznej zaczął się uwidaczniać. W 10 miastach zidentyfikowano zaawansowaną skalę starości (Poniec, Poznań, Borek Wielkopolski, Wieleń, Dolsk, Puszczykowo, Zagórów, Dąbie, Bojanowo, Przedecz), odsetek osób w wieku poprodukcyjnym przekroczył tam $15 \%$. 


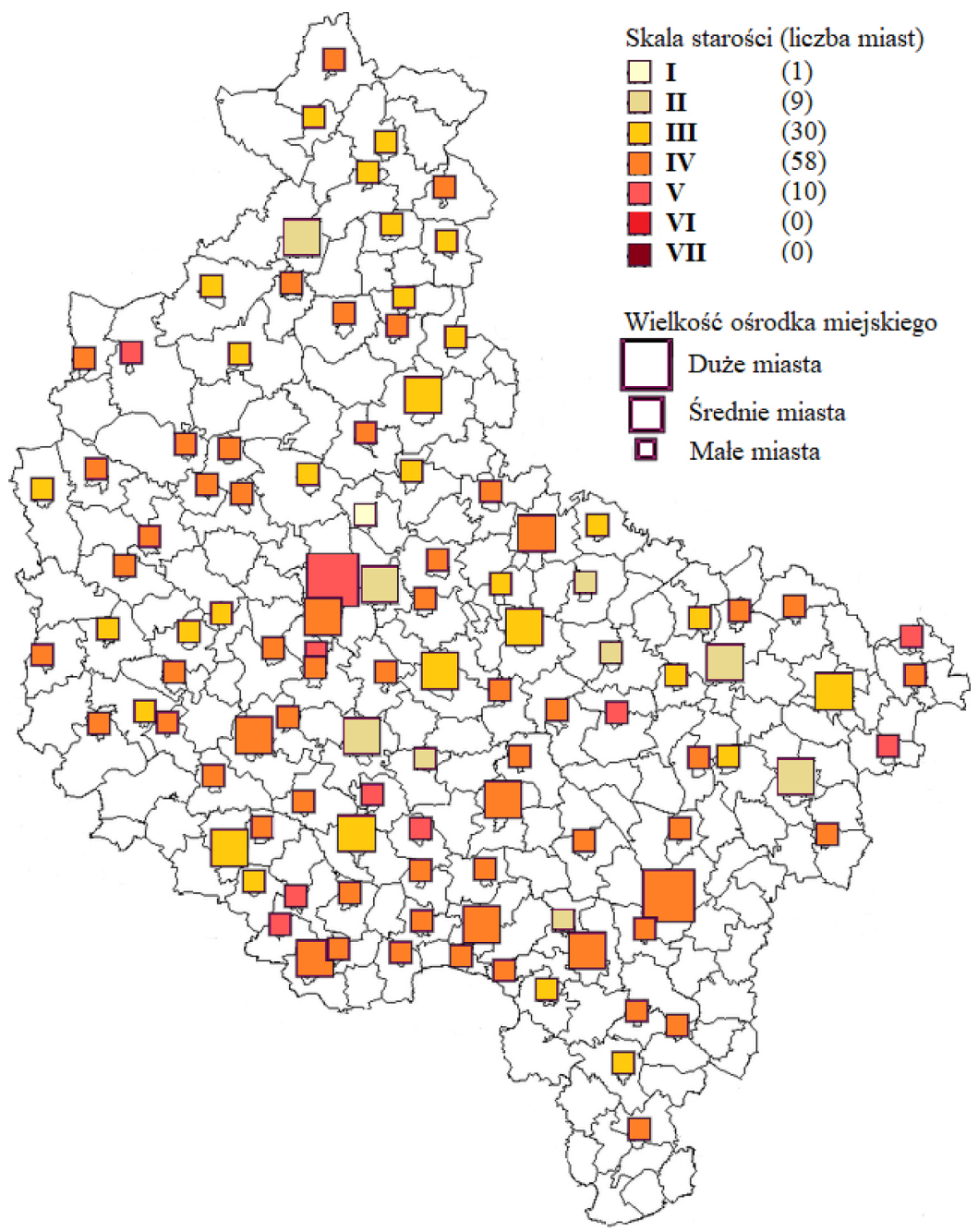

Ryc. 1. Rozkład miast według skal starości w 1995 r. w zależności od wielkości ośrodka miejskiego

Źródło: opracowanie własne na podstawie danych BDL, GUS.

Od 2010 r. w miastach odnotowano przyspieszenie tempa starzenia się ludności. Zmiany te w 2010 r. dostrzeżono przede wszystkim w miastach dużych i średnich (z wyjątkiem Swarzędza, Lubonia i Śremu), które zaliczono do ośrodków z zaawansowanym stanem starości demograficznej. Do 2018 r. w miastach województwa wielkopolskiego nasiliło się zjawisko starzenia się społeczeństwa. Ludność w wieku poprodukcyjnym przekroczyła wówczas 15\% mieszkańców. W tym analizowanym okresie zaobserwowano również w dwóch miastach anormalnie wysoki stan starości (Kalisz, Konin), gdzie ponad 25\% mieszkańców stanowiły osoby starsze. 


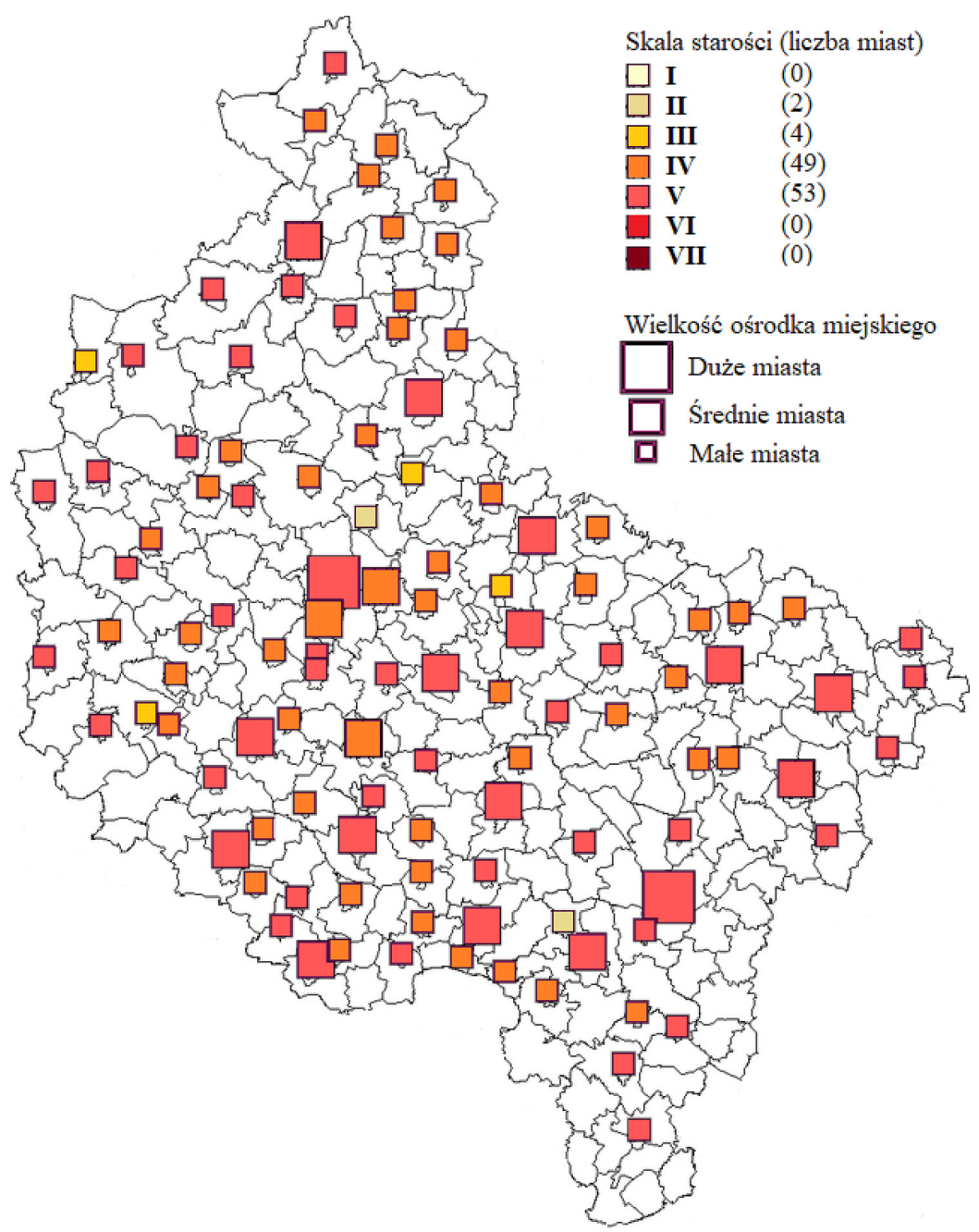

Ryc. 2. Rozkład miast według skal starości w 2010 r. w zależności od wielkości ośrodka miejskiego

Źródło: opracowanie własne na podstawie danych BDL, GUS.

Analizowany okres (1995-2018) ukazuje niezwykle szybkie zaawansowanie problemu starzenia się ludności. W niektórych miastach w 2018 r. w porównaniu do 1995 r. nasilenie zjawiska wiązało się z niewielkim wzrostem odsetka osób starszych o 2-3 p.p. (Pogorzela - 1,96 p.p., Przedecz - 2,33 p.p., Kobylin - 2,78 p.p., Dolsk - 2,9 p.p., Borek Wielkopolski - 2,99 p.p.), w innych o ponad 10 p.p. (najwięcej w Koninie - 16,41 p.p., Słupcy - 14,88 p.p., Kole - 14,46 p.p., Turku $-14,20$ p.p.).

Wzrost udziału ludności poprodukcyjnej wiązał się ze zmianą typu starości w kolejnych latach. Miasta, takie jak Borek Wielkopolski, Dolsk oraz Zagórów, 


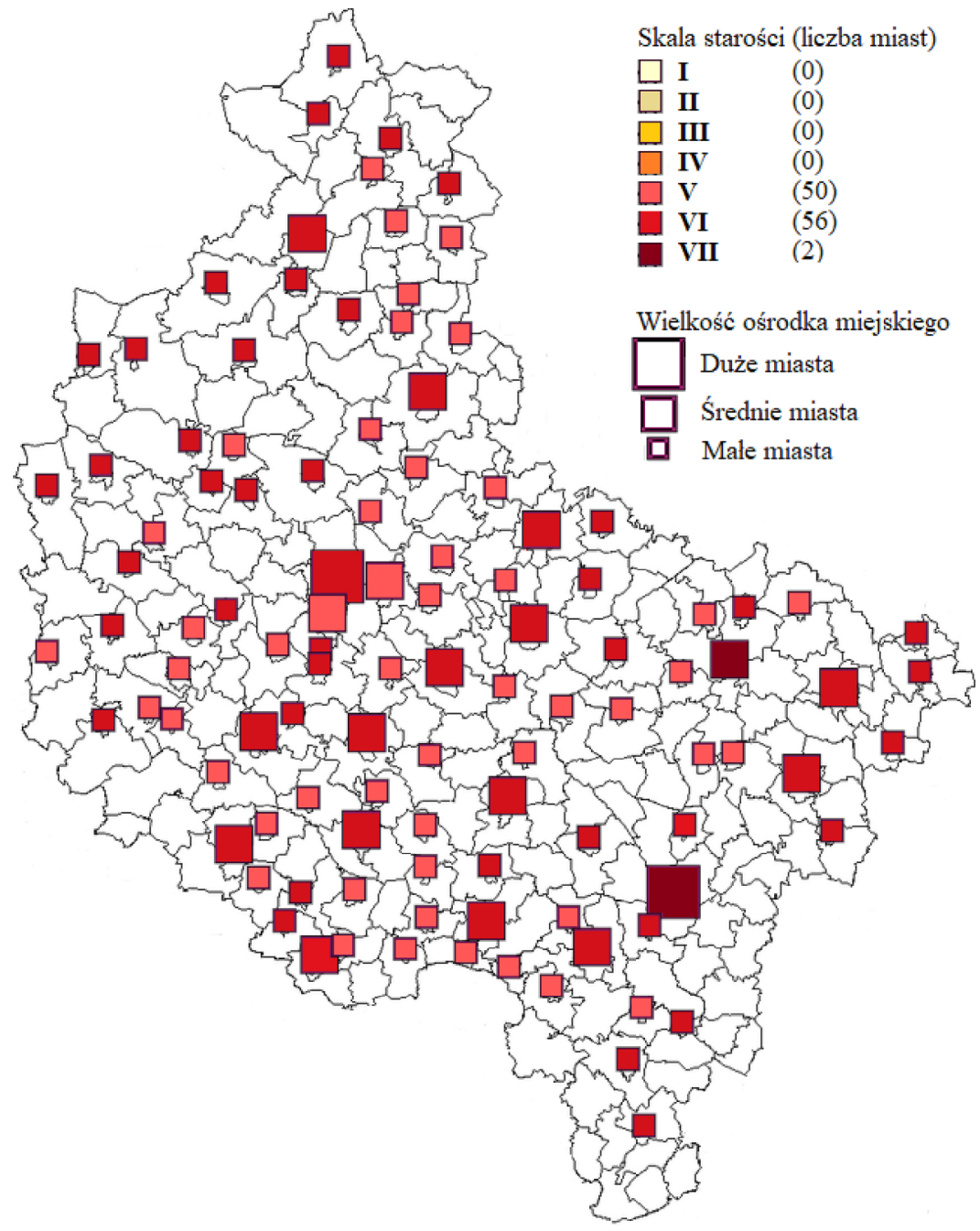

Ryc. 3. Rozkład miast według skal starości w 2018 r. w zależności od wielkości ośrodka miejskiego

Źródło: opracowanie własne na podstawie danych BDL, GUS.

które zaobserwowały mniejsze następstwo omawianego zjawiska, nie zmieniły swojego typu starości (od 1995 r. wykazywały zaawansowany stan starości - typ V). Nie świadczy to jednak o korzystnym położeniu tych jednostek w kontekście omawianych badań. Należy bowiem zaznaczyć, że miasta te, klasyfikując się w 1995 r. do typu V, już wtedy zmagały się z wysokim odsetkiem populacji seniorów, w przedziale 15-19,9\%. Niezmienny poziom według wyodrębnionej skali może znajdować swoje podłoże również w samej konstrukcji podziału Prochownikowej, chodzi o szeroką w stosunku do poprzednich typów rozpiętość przedziału. Pozostałe miasta poprzez rosnący odsetek osób starszych przeniosły się 
do grupy ośrodków znacząco nasilonych pod kątek wyodrębnionego problemu. W ten sposób do 2018 r. w 36 miastach doszło do przesunięcia o jeden stopień, tzn. nastąpiło przejście do kolejnego typu zaawansowania procesu starzenia się ośrodka miejskiego. W większości przypadków (29 ośrodków miejskich) dotyczyło to miast, w odniesieniu do których w 1995 r. zaobserwowano typ V (zaawansowany stan starości). Tym samym w 2018 r. tworzyły grupę miast z wysokim stanem starości (typ VI - z odsetkiem osób starszych w przedziale 20-24,9\%). Blisko 40\% miast zanotowało wzrost o dwa typy starości w do $2018 \mathrm{r}$. Zmiana ta była najbardziej widoczna w miastach w początkowym stanie starości w $1995 \mathrm{r}$. W 2018 r. zaliczono je do typu miast z wysokim stanem starzenia się (typ VI). $\mathrm{W}$ pozostałej grupie miast województwa wielkopolskiego proces zmian miał znacznie bardziej dynamiczny przebieg. W 20 ośrodkach miejskich zaawansowanie starzenia się mieszkańców nasiliło się do tego stopnia, że do 2018 r. miasta te zaobserwowały przejście na skalę wyższą o trzy wskazane przez Prochownikową typy w porównaniu do $1995 \mathrm{r}$. Zmiana objęła prawie 40\% miast średnich województwa. W przypadku miast dojrzałych demograficznie (typ II - Piła, Słupca, Śrem, Turek, Witkowo) oraz Murowanej Gośliny (typ I - młodość demograficzna) w 1995 r. do 2018 r. odsetek osób starszych był bliski lub przekroczył 20\% (przejście do typu V). Zdecydowanie najgorzej w analizowanych okresach rozwinęła się sytuacja w Koninie - w 1995 r. zaliczony był do grupy miast dojrzałych demograficznie (typ II), w 2018 r. stał się ośrodkiem z anormalnym poziomem starości (typ VII), gdzie odsetek osób starszych przekroczył 25\%. Miasta województwa wielkopolskiego $z$ każdym analizowanym rokiem odnotowywały rosnący odsetek populacji seniorów. Ze wszystkich badanych jednostek wyodrębniły się dwa małe miasta, takie jak Murowana Goślina, gdzie odsetek osób starszych utrzymywał się na najniższym poziomie $(7,02 \% \mathrm{w} 1995$ r. i 15,32\% w 2018 r.), co należy wiązać z bezpośrednim sąsiedztwem Poznania, oraz Raszków. W mieście tym w latach 1995-2005 udział ludności poprodukcyjnej zmniejszał się, podczas gdy w sąsiadujących ośrodkach miejskich (Kalisz, Ostrów Wielkopolski, Krotoszyn) trend był zupełnie odwrotny.

Przesunięcia miast $\mathrm{w}$ wyodrębnionych poziomach starości prezentują szybkość nasilania się zjawiska. W ośrodkach miejskich, gdzie do 2018 r. nastąpiło przejście o trzy, cztery, a nawet pięć typów w porównaniu do 1995 r., wzrost odsetka populacji seniorów oscylował w przedziale 5-15\%. Reasumując, część miast zanotowała ponaddwukrotny (np. Konin) wzrost osób starszych w strukturze populacji w ciągu 23 lat. Niemniej jednak należy zaznaczyć, że utrzymanie $\mathrm{w}$ tej samej grupie rozkładu lub przesunięcie o jeden typ starości miast nie wiązało się w przypadku ośrodków miejskich $\mathrm{w}$ Wielkopolsce $z$ efektem pozytywnym. Mniejsze tempo wzrostu odsetka osób starzejących się uzależnione było od wysokiej skali starości zidentyfikowanej w 1995 r. (chodzi o typ V i VI) oraz szerokich przedziałów w skali Prochownikowej.

Ponieważ w 2018 r. ośrodki miejskie województwa wielkopolskiego wykazywały trzy typy starości, błędem jest powiązanie skali zaawansowania analizowanego zjawiska $z$ położeniem względem miasta Poznania. Słuszne jest za to stwierdzenie o zależności typu starości od wielkości miasta. W 1995 r. najwyższy 
wówczas poziom starzenia się (skala V) zidentyfikowano w małych miastach, wyjątkiem był Poznań. Do grupy ośrodków dojrzałych demograficznie (skala II) należały w równym stosunku miasta średnie i małe. Do 2018 r. zjawisko przybrało nieco odwrotny kierunek. Wówczas do grupy ośrodków miejskich najbardziej dotkniętych omawianym problemem weszły prawie wszystkie miasta średnie (z wyjątkiem Lubonia i Swarzędza).

\section{Podsumowanie i dyskusja}

Zjawisko starzenia się populacji ma miejsce na całym świecie. Za najbardziej znaczący okres w całym procesie uznaje się pierwszą połowę XXI w. (Rowland 2009), po 2050 r. prognozuje się zakończenie problemu starzenia się ludności (Sanderson i in. 2018). Wysoki odsetek populacji seniorów jest równoznaczny $\mathrm{z}$ procesem społecznych zmian, kreujących nowe tendencje $\mathrm{w}$ funkcjonowaniu społeczeństw. Kluczowa jest zatem zmiana m.in. polityk, postaw czy praktyk w taki sposób, by osoby starsze nie były postrzegane jako beneficjenci pomocy społecznej, lecz aktywni uczestnicy w procesie rozwoju.

Artykuł jest próbą spojrzenia na zjawisko starzenia się społeczeństwa z punktu widzenia skali zaawansowania procesu. Analiza miast województwa wielkopolskiego pozwoliła wyodrębnić typy starości demograficznej, a dynamiczne ujęcie pokazywało ewolucję poziomu jego nasilenia w badanych miastach. Zaprezentowana skala starości miast jest uniwersalnym przykładem analiz, który ograniczono terytorialnie do wybranego województwa w celu sprawdzenia, czy próba wyodrębnienia typów zaawansowania procesu starzenia jest możliwa (głównie ze względu na przedstawione przez autorów przedziały i obawę co do ich adekwatności $\mathrm{w}$ stosunku do współczesnych zjawisk starzenia społeczeństwa). Identyfikacja jednostek w ostatnim typie (anormalnie wysokiego stopnia starości - typ VII) w ramach zaproponowanej przez Prochownikową skali wzbudza dyskusję nad tym, czy w badaniach naukowych nie powinno się podjąć próby stworzenia nowych skal starości. „Współczesne skale” zaawansowania procesu starzenia się byłyby odpowiedzią na prognozy demograficzne (Sytuacja demograficzna osób starszych... 2014, World Population Prospects... 2019), w których przewiduje się dalszy przyrost osób starszych w strukturze ludności. Spostrzeżenie to potwierdza również przeprowadzone $\mathrm{w}$ ramach artykułu badanie i wyniki dla 2015 i 2018 r., w których do typu I, II i III nie przyporządkowano żadnego miasta z województwa wielkopolskiego.

W artykule ograniczono się do analizy przebiegu procesu zaawansowania starzenia się ludności miast województwa wielkopolskiego w ujęciu dynamicznym, odpowiadając tym samym na pytanie: o ile bądź w jakim stopniu nasiliło się zjawisko starzenia się miast. W ten sposób poszerzono dotychczasowe obserwacje naukowe o identyfikacje skal starości demograficznej, wskazując zróżnicowanie przestrzenne omawianego zjawiska w miastach województwa wielkopolskiego. Wyodrębnienie typów starości podkreśliło niepokojące zmiany ilościowe i jakościowe, bowiem rosnąca populacja seniorów w miastach jest równoznaczna 
z kolejnymi wyzwaniami dla polityki i planowania przestrzennego (Lechowska 2018). Złożoność wyzwań nie wiąże się jednak tylko i wyłącznie z koniecznością zaspokajania potrzeb osób starszych. Problem identyfikuje się również w sferze uwarunkowań procesu starzenia się, czyli chociażby zjawiska migracji (Janiszewska, Dmochowska-Dudek 2017). Czynniki demograficzne są bowiem kluczowymi determinantami kształtowania zjawiska starzenia się społeczeństwa.

Zjawisko starzenia się miast województwa wielkopolskiego postępowało z każdym analizowanym okresem. Do 2010 r. w większości miast obserwowano początkowy stan starości (typ IV), po czym do 2018 r. nastąpiło znaczące nasilenie zjawiska starzenia się mieszkańców miast. Świadczy o tym m.in. liczba ośrodków miejskich dotkniętych wysokim stanem starości - typ VI (ponad 50\% miast z odsetkiem osób starszych przekraczającym 20\%). Patrząc jednak z punktu widzenia wszystkim typów starości wyodrębnionych w wielkopolskich miastach w 2018 r., należy stwierdzić, że zmagały się one z zaawansowanym stanem starości, ponieważ we wszystkich analizowanych ośrodkach udział osób w wieku poprodukcyjnym w strukturze ludności przekroczył $15 \%$.

Badania pokazały, jak miasta ewoluowały pod kątem procesu starzenia się swoich mieszkańców. Pozwoliły wyodrębnić Konin jako ośrodek, gdzie zjawisko to najszybciej się nasiliło, przybierając $\mathrm{w}$ ostatnim analizowanym roku miano anormalnie wysokiego (odsetek osób starszych przekroczył 25\% i wyniósł 25,46\%), podczas gdy w $1995 \mathrm{r}$. należał do grupy miast dojrzałych demograficznie z 9-procentowym udziałem ludności poprodukcyjnej w strukturze mieszkańców.

Tempo starzenia się miast było dużo szybsze w większych ośrodkach aniżeli w małych miastach. Przykładem może być wspomniany wcześniej Konin, a także Kalisz, Słupca, Turek czy Gniezno, o których w 1995 r. można było mówić w kategoriach ośrodków dojrzałych demograficznie lub wykazujących przedpole starzenia się. W tym samym czasie liczna część małych miast obserwowała początkowy stan starości (typ IV), a niektóre proces zaawansowanego starzenia się (typ V - np. w Dąbiu, Przedczu oraz Bojanowie).

Analiza ponad 20-letniego okresu przeobrażeń skali starości demograficznej miast województwa wielkopolskiego podkreśla zaawansowanie współczesnego trendu demograficznego, który znajduje ujęcie globalne. Patrząc z punktu widzenia wyraźnego nasilenia się zjawiska, należy się spodziewać wzrostu liczby miast $\mathrm{w}$ anormalnie wysokim stanie starości (typ VII). Uzasadnia do argument, nieujęty we wcześniejszej części artykułu, mówiący o tym, że w 2018 r. miasta, takie jak: Koło, Poznań, Chodzież czy Turek, były bardzo bliskie przekroczenia progu $25 \%$ odsetka osób starszych. W takiej sytuacji znajdowało się również wiele miast $z$ zaawansowanym stanem starzenia się (ośrodki typu V). Należy się zatem spodziewać wyraźnych przesunięć w skali starości miast województwa wielkopolskiego, które nastąpią w ciągu kolejnego roku. Zasadne są zatem dalsze badania w kontekście czynników demograficznych odpowiadających za skalę nasilenia zaawansowania starzenia się miast województwa wielkopolskiego.

Mimo że badania ograniczyły się do wskazania typów starości miast w Wielkopolsce, ich identyfikacja może zostać wykorzystana w praktyce. Artykuł zawiera bowiem diagnozę sytuacji w województwie, prezentując zróżnicowanie 
nasilenia problemu starzenia się miast poprzez przyporządkowanie miastom typu starości. W ten sposób m.in. wyznaczono miasta $z$ anormalnie wysokim stanem starości, które wymagają koniecznych działań w dziedzinie nie tylko polityki senioralnej, lecz zarządzania rozwojem ośrodka miejskiego. Klasyfikacja miast województwa wielkopolskiego, identyfikując skalę starzenia się jego mieszkańców, jest sygnałem wobec kreowania polityk skupionych nie tylko na kwestiach zaspokajania potrzeb populacji seniorów (opieka zdrowotna, pomoc społeczna, łatwo dostępny transport), lecz na aktywnym włączeniu ich w życie społeczne i rozwój miast.

\section{Literatura}

Abramowska-Kmon A. 2011. O nowych miarach zaawansowania procesu starzenia się ludności. Studia Demograficzne, 1: 3-22.

Ageing in Cities. Policy highlights. 2015. OECD, Paryż.

Ageing in the Twenty-First Century: A Celebration and A Challenge. Executive Summary. 2012. United Nations Population Fund (UNFPA), New York.

Antczak E., Lewandowska-Gwarda K. 2018. Dynamika procesu starzenia się ludności w Polsce. Ocena z wykorzystaniem metod strukturalno-geograficznych. Studia Regionalne i Lokalne, 4: 89-110.

BDL, GUS (https://bdl.stat.gov.pl/BDL/start; dostęp: 24.01.2020).

Bloom D., Luca D. 2016. The Global Demography of Aging: Facts, Explanations, Future. IZA Discussion Paper, 10163, The Institute for the Study of Labor. Bonn.

Czekanowski P. 2012. Społeczne aspekty starzenia się ludności w Polsce. Perspektywa socjologii starości. Wydawnictwo Uniwersytetu Gdańskiego, Gdańsk.

d'Albis H., Collard F. 2013. Age groups and the measure of population aging. Demographic Research, 29: 617-640.

Długosz Z., Biały S. 2013. Starzenie się ludności Polski na tle Europy w perspektywie 2030 i 2050 r. W świetle wybranych parametrów. [W:] P. Raźniak (red.), Społeczno-ekonomiczne przemiany regionów. Krakowskie Towarzystwo Edukacyjne sp. z o.o. - Oficyna Wydawnicza AFM, Kraków, s. 9-20.

Długosz Z., Rachwał T. 2000. Starzenie się ludności w dużych miastach Polski na tle pozostałych ośrodków i obszarów wiejskich. Prace Geograficzne, 209: 29-37.

Domański B., Noworól A. (red.) 2010. Badanie funkcji, potencjału oraz trendów rozwojowych miast w województwie małopolskim. Uniwersytet Jagielloński, Kraków.

Filas-Przybył S. 2017. Wpływ migracji na rozmieszczenie w przestrzeni miejskiej obszarów (klastrów) o wysokim poziomie starości demograficznej na przykładzie m. Poznania. [W:] J. Hrynkiewicz, A. Potrykowska (red.), Sytuacja demograficzna Wielkopolski jako wyzwanie dla polityki społecznej i gospodarczej. Rządowa Rada Ludnościowa, Warszawa, s. 89-102.

Global age-friendly cities: a guide. 2007. World Health Organization, Genewa.

Głoskowska K. 2015. Rola gminy wobec problemu starzenia się społeczeństwa polskiego. Prace Naukowe WWSZIP, 3: 105-115.

Górecka S., Kozieł R. 2004. Procesy demograficzne w największych miastach Polski w okresie transformacji. [W:] J. Słodczyk, D. Rajchel (red.), Przemiany demograficzne i jakość życia ludności miast. Wydawnictwo Uniwersytetu Opolskiego, Opole, s. 27-40.

Janiszewska A., Dmochowska-Dudek K. 2017. Przestrzenne zróżnicowanie starzenia się ludności w Łodzi. Space-Society-Economy, 20: 9-22.

Kaplan M., Inguanzo M. 2017. The social, economic, and public health consequences of global population aging: implications for social work practice. Journal of Social Work in the Global Community, 1: 1-12

Kowaleski J.T. 2003. Kwestie metodologiczne w badaniu procesu starzenia się ludności. [W:] Z. Strzelecki (red.), Procesy demograficzne u progu XXI wieku. Polska a Europa. Warszawa, s. 306-312. 
Kowaleski J.T., Majdzińska A. 2012. Starzenie się populacji krajów Unii Europejskiej - nieodległa przeszłość i prognoza. Studia Demograficzne, 1: 57-80.

Kurek S. 2008. Typologia starzenia się ludności Polski w ujęciu przestrzennym. Wydawnictwo Naukowe AP, Kraków.

Labus A. 2013. Odnowa miast a starzejące się społeczeństwa europejskie na wybranych przykładach. Problemy Rozwoju Miast, 2: 11-27.

Lechowska E. 2018. Piesza dostępność wybranych przestrzeni miasta w dobie starzejącego się społeczeństwa na przykładzie Poznania. Rozwój Regionalny i Polityka Regionalna, 43: 83-108.

Miszczak E. 2015. Starość i starzenie się społeczeństw - przyczyny, uwarunkowania oraz prognozy na przyszłość. Edukacja Etyczna, 9: 5-16.

Podogrodzka M. 2016. Wybrane miary starości demograficznej i ich implikacja dla oceny przestrzennego zaróżnicowania tego zjawiska w Polsce. Studia Ekonomiczne. Zeszyty Naukowe Uniwersytetu Ekonomicznego w Katowicach, 289: 98-108.

Prochownikowa A. 1983. Problem starzenia się ludności wsi (na przykładzie województwa miejskiego krakowskiego). Zakład Narodowy im. Ossolińskich - Wydawnictwo Polskiej Akademii Nauk, Wrocław.

Richert-Kaźmierska A. 2016. Demograficzne starzenie się populacji jako wyzwanie dla samorządu gminnego - doświadczenia gmin województwa pomorskiego. Polityka i Społeczeństwo, 3: 114128.

Rosset E. 1967. Ludzie starzy. Studium demograficzne. Polskie Wydawnictwo Ekonomiczne, Warszawa.

Rowland D. 2009. Global Population Aging: History and Prospects. [W:] P. Uhlenberg (red.), International Handbooks of Population, Springer, s. 37-65.

Sanderson W., Scherbov S., Gerland P. 2018. The end of population aging in high-income countries. Vienna Yearbook of Population Research, 16: 163-175.

Sauvy A. 1948. La population: ses lois, ses équilibres. Presses Universitaires de France. Paryż.

Sytuacja demograficzna osób starszych i konsekwencje starzenia się ludności Polski w świetle prognozy na lata 2014-2050. 2014. Główny Urząd Statystyczny, Warszawa.

Sytuacja osób starszych w Polsce w 2018 r. 2020. Główny Urząd Statystyczny, Warszawa.

Trzpiot G., Ojrzyńska A. 2014. Analiza ryzyka starzenia demograficznego wybranych miast w Polsce. Studia Ekonomiczne, 178, 14: 235-249.

Urbaniak A. 2017. Procesy starzenia się w środowisku wielkomiejskim w Polsce na początku XXI wieku. Wymiar demograficzny i społeczny. Zeszyty Naukowe Uniwersytetu Ekonomicznego w Krakowie, 3: 103-122.

van Hoof J., Kazak J.K., Perek-Białas J.M., Peek S. 2018. The challenges of urban ageing: making cities age-friendly in Europe. International Journal of Environmental Research and Public Health, $15(11)$.

Vaupel J., Kistowski K. 2008. Living longer in an ageing Europe: a challenge for individuals and societies. European View, 7: 255-263.

World Population Prospects 2019. 2019. United Nations, New York.

World Population Prospects. The 2010 Revision. Vol. I. Comprehensive Tables. 2011. United Nations, New York.

Żołędowski C. 2012. Starzenie sie ludności - Polska na tle Unii Europejskiej. Problemy Polityki Społecznej. Studia i Dyskusje, 17: 29-43.

\section{Demographic old age of cities in Wielkopolskie Voivodeship}

Abstract: The aim of the article is to determine the scale of demographic old age of cities in the Wielkopolska Voivodeship. The division proposed by Prochownikowa, in which the author distinguished seven degrees of old age, was used for this purpose. The classification made it possible to indicate the degree of advancement of population ageing in the studied cities. The spatial scope covered 108 cities in Wielkopolskie Voivodship. In order to observe the changes in time, the research covered 1995, 2000, 2005, 2010, 2015 and 2018. The dynamic approach made it possible to illustrate the scale and evaluation of the problem of demographic ageing of cities in Wielkopolska. On the basis 
of the selected types, it was found that by 2010 the initial state of old age was observed in cities. By 2018, the percentage of elderly people in all urban centres exceeded 15\% (advanced old age), and in the case of Kalisz and Konin - 25\%, i.e. the scale of an abnormally high level of the residents' old age.

Key words: demography, aging society, cities, Wielkopolskie Voivodeship 